\section{Mycorrhizal Inoculation Enhances Growth and Development of Micropropagated Plants of Avocado}

\author{
M.T. Vidal, C. Azcón-Aguilar, and J.M. Barea \\ Departamento de Microbiología Estación Experimental del Zaidín, \\ 18008 Granada, Consejo Superior de Investigaciones Científicas, Spain
}

\author{
F. Pliego-Alfaro \\ Centro de Investigaci6n y Desarrollo Agrario, 29140-Churriana, \\ Málaga, Spain
}

Additional index words. Glomus fasciculatum, tissue culture, Persea americana

Abstract. Micropropagated plantlets of avocado (Persea americana Mill.) exhibit a very slow rate of growth during the acclimatization phase, possibly because mycorrhizae are absent. Inoculation of plantlets with the vesicular-arbuscular mycorrhizal fungus Glomus fasciculatum (Thaxter sensu Gerd) Gerd and Trappe improved formation of a well-developed root system that was converted into a mycorrhizal system. Introduction of the mycorrhizal fungus at the time plantlets were transferred from axenic conditions to ex vitro conditions improved shoot and root growth; enhanced the shoot : root ratio; increased the concentration and/or content of $N, P$, and $K$ in plant tissues; and helped plants to tolerate environmental stress at transplanting. Inclusion of soil as a component of the potting medium appeared to favor mycorrhiza formation and effectiveness. Thus, mycorrhiza formation seems to be the key factor for subsequent growth and development of micropropagated plants of avocado.
Fruit crops, like most horticultural plants, commonly develop vesicular-arbuscular mycorrhizae (VAM) relationships and exhibit a high degree of dependence on this symbiosis for normal development (Nemec, 1986). Propagation of these plants by tissue culture has become widely adopted. However, the media used not only for the in vitro stages (obviously sterile), but also for subsequent plantlet growth in potting substrates or in fumigated nursery beds usually lack VAM propagules. Therefore, plantlets should be inoculated early during micropropagation to achieve suitable growth (Gianinazzi et al., 1989).

Surface-sterilized spores and other VAM propagules are able to develop mycorrhizal relationships when inoculated during in vitro propagation of various horticultural species (Chavez and Ferrera-Cerrato, 1990), particularly woody plants (Pons et al., 1983; Ravolanirina et al., 1987). However, this technique presents several difficulties, such as differences in the conductive media for

Received for publication 7 June 1991. Accepted for publication 13 Jan. 1992. We thank CICYT, Agricultural Projects, for finanaical support. The cost of publishing this paper was defrayed in part by the payment of page charges. Under postal regulations, this paper therefore must be hereby marked advertisement solely to indicate this fact. root initiation and VAM formation and loss of roots produced during the in vitro stages after outplanting (Ravolanirina et al., 1987; Schubert et al., 1990). In contrast, inoculation at the time of transplanting of the axenically propagated plantlets into the potting media appears feasible and promising ( $\mathrm{Ra}-$ volanirina et al., 1989a; Schubert et al.,
1990). Mycorrhizal inoculation of in vitropropagated transplants has proven to be effective in respect to tolerance to transplant stress and improvement of growth and mineral nutrient status (Gianinazzi et al., 1989).

Research is being conducted worldwide to integrate biotechnological approaches, mycorrhizal inoculation, and micropropagation of various plant species. Avocado is a suitable test plant for this purpose because of its mycotrophic habit (Menge, 1983; Nemec, 1986) and commercial value. Successful micropropagation of this plant appears problematic because of difficulties in rooting (Pliego-Alfaro and Murashige, 1987). Moreover, growth of micropropagated avocado plants is slow during the acclimatization phase. Consequently, VAM inoculation might be beneficial. Since, to our knowledge, there are no published reports on mycorrhizal inoculation of micropropagated avocado plants, the following research was conducted to investigate the influence of mycorrhizal inoculation on growth and development of in vitropropagated plantlets.

Micropropagation of host plant. Juvenile shoots were excised from in vitro-germinated seedlings of GvarAm-13 avocado rootstock (Kadman and Ben Ya'acov, 1980) following procedures of Barceló-Muñoz et al. (1990). Cultures were grown at 25C with a 16-h photoperiod provided by Sylvania GroLux fluorescent lamps. The lamps provided a photosynthetic photon flux (PPF) of 45 $\mu \mathrm{mol} \cdot \mathrm{s}^{-1} \cdot \mathrm{m}^{-2}$. Two weeks after being cultured on rooting medium (Barceló-Muñoz et al., 1990), shoots with visible root primordia were transferred to sealed glass flasks $(500$ $\mathrm{ml}$ ) containing $200 \mathrm{ml}$ of a medium of 1 peat : 1 perlite (v/v). Four plantlets per flask were
Table 1. Influence of vesicular-arbuscular mycorrhizal (VAM) colonization on shoot growth and mineral nutrient status of in vitro-propagated plantlets of avocado inoculated with Glomus fasciculatum at the beginning of the acclimatization stage (Expt. 1).

\begin{tabular}{|c|c|c|c|c|c|c|c|c|}
\hline \multirow[b]{2}{*}{ Treatment } & \multirow{2}{*}{$\begin{array}{c}\text { VAM } \\
\text { colonization } \\
\text { (\% root length) }\end{array}$} & \multirow{2}{*}{$\begin{array}{l}\text { Shoot } \\
\text { dry wt } \\
\text { (g) }\end{array}$} & \multicolumn{6}{|c|}{ Shoot mineral nutrient status } \\
\hline & & & $(\%)$ & $\begin{array}{l}\mathrm{N} \\
\text { (mg/plant) }\end{array}$ & $(\%)$ & $\begin{array}{l}\mathrm{P} \\
\text { (mg/plant) }\end{array}$ & $(\%)$ & $\begin{array}{l}\mathrm{K} \\
\text { (mg/plant) }\end{array}$ \\
\hline $\begin{array}{l}\text { Noninoculated } \\
\text { Inoculated }\end{array}$ & $\begin{array}{c}0 \mathrm{a}^{\mathrm{z}} \\
83.7 \mathrm{~b}\end{array}$ & $\begin{array}{l}0.2 \mathrm{a} \\
1.2 \mathrm{~b}\end{array}$ & $\begin{array}{l}2.44 \mathrm{a} \\
1.76 \mathrm{a}\end{array}$ & $\begin{array}{r}5.0 \mathrm{a} \\
20.0 \mathrm{~b}\end{array}$ & $\begin{array}{l}0.06 \mathrm{a} \\
0.08 \mathrm{a}\end{array}$ & $\begin{array}{l}0.1 \mathrm{a} \\
1.0 \mathrm{~b}\end{array}$ & $\begin{array}{l}0.68 \mathrm{a} \\
0.82 \mathrm{a} \\
\end{array}$ & $\begin{array}{l}1.5 \mathrm{a} \\
9.2 \mathrm{~b}\end{array}$ \\
\hline
\end{tabular}

${ }^{2}$ Mean separation in columns by Student's $t$ test, $P=0.05$.

Table 2. Effects of Glomus fasciculatum inoculation on survival, growth, and devclopment of in vitropropagated plantlets of avocado inoculated at transplanting to open pots containing a medium of 1 peat : 1 perlite $(\mathrm{v} / \mathrm{v})($ Expt. 2).

\begin{tabular}{|c|c|c|c|c|c|c|c|}
\hline \multirow[b]{2}{*}{ Treatment } & \multirow{2}{*}{$\begin{array}{c}\text { Survival } \\
(\%)\end{array}$} & \multirow{2}{*}{$\begin{array}{l}\text { Shoot ht } \\
\text { (cm) }\end{array}$} & \multirow[b]{2}{*}{ Leaf no. } & \multirow{2}{*}{$\begin{array}{c}\text { VAM }^{z} \\
\text { colonization } \\
\text { (\% root length) }\end{array}$} & \multicolumn{2}{|c|}{ Dry wt (g) } & \multirow{2}{*}{$\begin{array}{l}\text { Shoot : root } \\
\text { ratio }\end{array}$} \\
\hline & & & & & Shoot & Root & \\
\hline $\begin{array}{l}\text { Noninoculated } \\
\text { Inoculated }\end{array}$ & $\begin{array}{l}5.6 \mathrm{a}^{\mathrm{y}} \\
35.2 \mathrm{~b}\end{array}$ & $\begin{array}{l}3.5 \mathrm{a} \\
9.3 \mathrm{~b}\end{array}$ & $\begin{array}{r}8.0 \mathrm{a} \\
16.1 \mathrm{~b}\end{array}$ & $\begin{array}{c}0 \mathrm{a} \\
46.4 \mathrm{~b}\end{array}$ & $\begin{array}{l}0.2 \mathrm{a} \\
1.0 \mathrm{~b}\end{array}$ & $\begin{array}{l}0.1 \mathrm{a} \\
0.3 \mathrm{~b}\end{array}$ & $\begin{array}{l}1.8 \mathrm{a} \\
3.2 \mathrm{~b}\end{array}$ \\
\hline
\end{tabular}

${ }^{2} \mathrm{VAM}=$ vesicular-arbuscular mycorrhizac.

'Mean separation in columns by Student's $t$ test, $P=0.05$. 
Table 3. Effect of Glomus fasciculatum inoculation on the mineral nutrient status of in vitro-propagated plantlets of avocado inoculated at transplanting to open pots containing a medium of 1 peat : 1 perlite (by volume) (Expt. 2).

\begin{tabular}{|c|c|c|c|c|c|c|c|c|c|c|c|c|}
\hline \multirow[b]{2}{*}{ Treatment } & \multicolumn{6}{|c|}{ Shoot } & \multicolumn{6}{|c|}{ Root } \\
\hline & $(\%)$ & $\begin{array}{l}\mathrm{N} \\
\text { (mg/plant) }\end{array}$ & $(\%)$ & $\begin{array}{l}\mathbf{P} \\
\text { (mg/plant) }\end{array}$ & (\%) & $\underset{\text { (mg/plant) }}{\mathrm{K}}$ & $(\%)$ & $\begin{array}{l}\mathrm{N} \\
\text { (mg/plant) }\end{array}$ & $(\%)$ & $\begin{array}{l}\mathrm{P} \\
\text { (mg/plant) }\end{array}$ & $(\%)$ & $\begin{array}{l}\mathrm{K} \\
\text { (mg/plant) }\end{array}$ \\
\hline $\begin{array}{l}\text { Noninoculated } \\
\text { Inoculated }\end{array}$ & $\begin{array}{l}1.54 \mathrm{a}^{x} \\
1.73 \mathrm{a}^{2}\end{array}$ & $\begin{array}{r}3.2 \mathrm{a} \\
18.4 \mathrm{~b}\end{array}$ & $\begin{array}{l}0.07 \mathrm{a} \\
0.17 \mathrm{~b}\end{array}$ & $\begin{array}{l}0.2 \mathrm{a} \\
1.8 \mathrm{~b}\end{array}$ & $\begin{array}{l}0.80 \mathrm{a} \\
1.15 \mathrm{a}\end{array}$ & $\begin{array}{r}1.7 \mathrm{a} \\
12.3 \mathrm{~b}\end{array}$ & $\begin{array}{l}1.33 \mathrm{a} \\
1.56 \mathrm{a}\end{array}$ & $\begin{array}{l}1.6 \mathrm{a} \\
5.1 \mathrm{~b}\end{array}$ & $\begin{array}{l}0.04 a \\
0.16 b\end{array}$ & $\begin{array}{l}0.1 \mathrm{a} \\
0.5 \mathrm{~b}\end{array}$ & $\begin{array}{l}0.87 \mathrm{a} \\
1.01 \mathrm{a}\end{array}$ & $\begin{array}{l}1.0 \mathrm{a} \\
3.0 \mathrm{~b}\end{array}$ \\
\hline
\end{tabular}

${ }^{2}$ Mean separation in columns by Student's $t$ test, $P=0.05$.

Table 4. Effect of Glomus fasciculatum inoculation on survival, growth, and mineral nutrient status of in vitro-propagated plantlets of avocado inoculated at transplanting to open pots containing a medium of 1 soil : 1 sand (v/v) (Expt. 3).

\begin{tabular}{|c|c|c|c|c|c|c|c|c|c|c|c|}
\hline \multirow[b]{3}{*}{ Treatment } & \multirow{3}{*}{$\begin{array}{c}\text { Survival } \\
(\%)\end{array}$} & \multirow{3}{*}{$\begin{array}{c}\text { VAM }^{\mathbf{z}} \\
\text { colonization } \\
\text { (\% root length) }\end{array}$} & \multirow{2}{*}{\multicolumn{2}{|c|}{ Dry wt $(\mathrm{g})$}} & \multirow{3}{*}{$\begin{array}{l}\text { Shoot : root } \\
\text { ratio }\end{array}$} & \multicolumn{6}{|c|}{ Shoot nutrient status } \\
\hline & & & & & & \multirow[b]{2}{*}{$(\%)$} & \multirow{2}{*}{$\begin{array}{l}\mathrm{N} \\
\text { (mg/plant) }\end{array}$} & \multirow[b]{2}{*}{$(\%)$} & \multirow{2}{*}{$\begin{array}{l}\mathbf{P} \\
\text { (mg/plant) }\end{array}$} & \multirow[b]{2}{*}{$(\%)$} & \multirow{2}{*}{$\begin{array}{l}\mathrm{K} \\
\text { (mg/plant) }\end{array}$} \\
\hline & & & Shoot & Root & & & & & & & \\
\hline $\begin{array}{l}\text { Joninoculate } \\
\text { noculated }\end{array}$ & $\begin{array}{l}25.0 \mathrm{a}^{\mathrm{y}} \\
72.5 \mathrm{~b}\end{array}$ & $\begin{array}{c}0 \mathrm{a} \\
79.2 \mathrm{~b}\end{array}$ & $\begin{array}{l}0.9 \mathrm{a} \\
5.2 \mathrm{~b}\end{array}$ & $\begin{array}{l}0.8 \mathrm{a} \\
3.0 \mathrm{~b}\end{array}$ & $\begin{array}{l}1.3 \mathrm{a} \\
1.7 \mathrm{~b}\end{array}$ & $\begin{array}{l}1.80 \mathrm{a} \\
1.81 \mathrm{a}\end{array}$ & $\begin{array}{l}16.2 \mathrm{a} \\
86.1 \mathrm{~b}\end{array}$ & $\begin{array}{l}0.04 \mathrm{a} \\
0.09 \mathrm{~b}\end{array}$ & $\begin{array}{l}0.4 \mathrm{a} \\
4.8 \mathrm{~b}\end{array}$ & $\begin{array}{l}1.03 \mathrm{a} \\
0.95 \mathrm{a}\end{array}$ & $\begin{array}{r}9.3 \mathrm{a} \\
39.0 \mathrm{~b}\end{array}$ \\
\hline
\end{tabular}

${ }^{2}$ VAM $=$ vesicular-arbuscular mycorrhizae.

yean separation in columns by Student's $t$ test, $P=0.05$.

kept in a greenhouse for 4 weeks (acclimatization stage I). At the end of this period, plantlets usually had only two primary roots and few, if any, secondary roots. At this stage, they were transplanted individually to 250-ml open pots (one per pot) and placed in a misting tunnel ( $100 \%$ relative humidity) for an additional 4 weeks before their transfer to normal greenhouse conditions (see below).

Mycorrhizal inoculum. Glomus fasciculatum was chosen among various VAMforming isolates after a previous selection for functional compatibility with the micropropagated avocado plants. The inoculum consisted of washed mycorrhizal roots with the external mycelium and spores attached, but free from soil particles. Inoculum [ $1 \mathrm{~g}$ (fresh weight)], cut into $1-\mathrm{cm}$ fragments, was applied to each plantlet close to the root system. Filtered [Whatman 1 filter paper (Whatman Intl., Maidstone, England)] leachates of the root inoculum were applied to nontreated plantlets to compensate for the free-living microbiota associated with the mycorrhizal inoculum.

Growing conditions. Inoculated and noninoculated (control) plants were grown in a greenhouse with day/night temperatures ranging from 19 to $25 \mathrm{C}$. Daylength was extended to $16 \mathrm{~h}$ by cool-white fluorescent lamps, providing a PPF of $650 \mu \mathrm{mol} \cdot \mathrm{s}^{-1} \cdot \mathrm{m}^{-2}$. Plantlets were fertilized weekly with $10 \mathrm{ml}$ of full-strength Long Aston nutrient solution (Hewitt, 1952) and watered daily. In addition to the in vitro and the two acclimatization stages, a further 20 weeks of growth in the greenhouse was allowed before harvest.

Design of experiments. Three experiments were conducted. Each used a completely random arrangement of two treatments (noninoculated and inoculated plants). A treatment consisted of 50 replicate pots for Expt. 1, 54 for Expt. 2, and 40 for Expt. 3.

Recording of data. Dry weight of shoots and roots was recorded after harvesting and drying for $24 \mathrm{~h}$ at $65 \mathrm{C}$, and plant tissues were analyzed for $\mathrm{N}, \mathrm{P}$, and $\mathrm{K}$ (Lachica et al., 1973). The amount of root system with VAM colonization was assessed by a stain- ing procedure (Phillips and Hayman, 1970), and the percentage of the total root length that became colonized by mycorrhizae was determined using the gridline intersect technique (Giovannetti and Mosse, 1980).

Statistical analysis. Student's t test was used for statistical analysis of data. In the case of the values given as percentages, data were subjected to an arcsin square-root transformation to ensure homogeneity of variances.

Flask inoculation (Expt. 1). Mycorrhizal inoculation was performed at the beginning of the acclimatization stage in the glass flasks with the intent to establish the mycorrhizal symbiosis as soon as possible in the ex vitro phase. After this stage of acclimatization, plantlets were transferred to open pots containing a steam-sterilized growing medium of 5 soil : 2 sand (v/v). The soil consisted of clay, $42.5 \%$; silt, $34.0 \%$; sand, $23.5 \%$; organic matter, $1.18 \%$; total N, $0.18 \%$; and contained extractable $\mathrm{P}$ at 6.1 and $\mathrm{K}$ at 0.7 $\mathrm{mg} \cdot \mathrm{kg}^{-1}$. The soil was taken from the experimental field at Zaidín.

Pot inoculation (peat : perlite) (Expt. 2). Plants were inoculated when transferred from the flask to open-pot conditions. The potting medium consisted of 1 peat : 1 perlite $(\mathrm{v} / \mathrm{v})$. Percent survival, shoot height, and number of leaves were recorded after 20 weeks of growth.

Pot inoculation (soil : sand) (Expt. 3). Plantlets were inoculated at transplanting to open pots, and the substrate used was 1 soil : 1 sand (v/v). Percent survival was determined after 20 weeks of growth at the end of the experiment.

Flask inoculation. Almost the entire root system of the inoculated plantlets was heavily colonized by the VAM fungus at the end of the experiment (Table 1). Since relatively few secondary roots were induced in the flask acclimatization stage and determination of mycorrhizal colonization was destructive, colonization was not measured before transplanting to pots. Many explants in the flask died, probably due to microbial contamination derived from the experimental conditions. At the pot phase, however, the transplanted, healthy plantlets responded well to VAM inoculation. In fact, the inoculation of $G$. fasciculatum enhanced both growth and nutrient content of plant shoots (Table 1). Noninoculated plantlets developed and grew poorly relative to those inoculated. Inoculation with $G$. fasciculatum, therefore, was beneficial, but because of high mortality of explants, it appeared more appropriate to introduce the inoculum at a different stage of acclimatization.

Pot inoculation (peat : perlite). Survival and growth (Table 2) and mineral nutrient status (Table 3 ) of plantlets of avocado were significantly improved by mycorrhizal inoculation. Although plantlet survival following transplanting was low, it was significantly increased by mycorrhizal inoculation.

Pot inoculation (soil : sand). The soil : sand medium (Table 4) appeared to enhance VA mycorrhizal establishment in comparison to the peat : perlite medium (Table 2), with colonization levels of $\approx 80 \%$ of the total root length and a substantial arbuscular development. Also, survival following transplanting, plant growth, and, especially, mycorrhizal response were improved in soil : sand relative to peat : perlite.

Although acclimatization of micropropagated plants of avocado is difficult (BarcelóMuñoz et al., 1990), we here have shown a growth-promoting effect of mycorrhizal inoculation of plantlets during transition from the heterotrophic state (in vitro production) to the autotrophic state (grown in pots). Previous research has also reported beneficial effects of mycorrhizal inoculation on micropropagated fruit trees (Ravolanirina et al., 1987, 1989a, 1989b; Schubert et al., 1990).

Ravolanirina et al. (1989a, 1989b) have recommended that mycorrhizal inoculation be used shortly after explants are removed from culture vessels and at the beginning of root initiation. However, these recommendations do not appear optimal for avocado. Mycorrhizal colonization is known to take place only on young, secondary roots before suberization (Barea et al., 1992). Since these fine, young roots are produced by avocado later during ex vitro development, inocula- 
tion would be meaningless during the flask acclimatization stage, but advisable when transferred to open pots. Further, potting media can include sterilized soil, a substrate component that usually improves VAM formation in micropropagated plants (Gianinazzi et al., 1990). The apparent beneficial effect of the presence of soil in the growing medium on mycorrhiza formation appears to be confirmed by our results.

Because typical arbuscules were formed in the appropriate root cortical cells, VAM was probably functioning in its recognized role of improving nutrient acquisition by the host plant, as deduced from the enhancement of nutrient concentration and/or content in plant tissues found in our experiments. The effects of mycorrhizal inoculation on plant growth may also be due to improved rhizogenesis of the otherwise poorly rooted transplants, as has been suggested with other crops (Heslin and Douglas, 1986; Schubert et al., 1990). Since VAM fungi produce plant hormones (Barea and Azcón-Aguilar, 1982), they might improve root formation and development of in vitro-derived avocado plantlets. Additionally, mycorrhizal inoculation may have helped plantlets resist environmental stress at transplanting from axenic conditions to normal cultivation in open air, as has been demonstrated in other situations with VAM (Barea et al., 1992).

\section{Literature Cited}

Barceló-Muñoz, A., F. Pliego-Alfaro, and J.M. Barea. 1990. Micropropagación de aguacate (Persea americana Mill) en fase juvenil. Proc. Third Spanish Conf. Hort. Sci. Tenerife, Spain, Oct. 1988.

Barea, J.M. and C. Azcón-Aguilar. 1982. Production of plant growth-regulating substances by the vesicular-arbuscular mycorrhizal fungus Glomus mosseae. Applied Environ. Microbial. 43:810-813.

Barea, J.M., C. Azcón-Aguilar, and R. Azcón. 1992. Mycorrhiza and crops. In: I.C. Tommerup (ed.). Advances in plant pathology. Mycorrhiza: A synthesis. Academic, New York. (In press.)

Chávez, MC.G. and R. Ferrera-Cerrato. 1990. Effect of vesicular-arbuscular mycorrhizae on tissue culture-derived plantlets of strawberry. HortScience 25:903-905.

Gianinazzi, S., V. Gianinazzi-Pearson, and A. Trouvelot. 1989. Potentialities and procedures for the use of endomycorrhizas with special emphasis on high value crops, p. 41-54. In: J.M. Whipps and B. Lumsden (eds.). Biotechnology of fungi for improving plant growth. Cambridge Univ. Press. Cambridge. U.K.

Giovannetti, M. and B. Mosse. 1980. An evaluation of techniques for measuring vesicular-arbuscular mycorrhizal infection in roots. New Phytol. 84:489-500.

Heslin, M.C. and G.C. Douglas. 1986. Effects of ectomycorrhizal fungi on growth and development of poplar plants derived from tissue culture. Scientia Hort. 30:143-149.

Hewitt. E.J. 1952. Sand and water culture methods used in the study of plant nutrition. Farnham Royal Commonwealth Agr. Bur., Bucks, U.K. Tech. Commun. 22.

Kadman, A. and A. Ben Ya'acov. 1980. G.A.13 avocado rootstock selection. HortScience 15:206-208

Lachica, M., A. Aguilar, and J. Yañez. 1973.
Análisis foliar. Métodos analíticos utilizados en la Estación Experimental de1 Zaidín. Anales Edafología y Agrobiología 32:1033-1047.

Menge. J.A. 1983. Utilization of vesicular-arbuscular mycorrhizal fungi in agriculture. Can. J. Bot. 61:1015-1024.

Nemec, S. 1986. VA mycorrhizae in horticultural systems, p. 193-211. In: G.R. Safir (ed.). Ecophysiology of VA mycorrhizal plants. CRC, Boca Raton, Fla.

Phillips, J.M. and D.S. Hayman. 1970. Improved procedures for clearing roots and staining parasitic and vesicular-arbuscular mycorrhizal fungi for rapid assessment of infection. Trans. Brit. Mycol. Soc. 55:159-161.

Pliego-Alfaro, F. and T. Murashige. 1987. Possible rejuvenation of adult avocado by graftage onto juvenile rootstocks in vitro. HortScience 22:1321-1324.

Pons, F., V. Gianinazzi-Pearson, S. Gianinazzi, and J.C. Navatel. 1983. Studies of VA mycorrhizae in vitro: Mycorrhizal synthesis of axen- ically propagated wild cherry (Prunus avrum L.) plants: Plant \& Soil 71:217-221.

Ravolanirina, F.. B. Blai. S. Gianinazzi. and V. Gianinazzi-Pearson. 1989b. Mise au point d'une method rapide d'endomycorhization de vitroplants. Fruits 44:165-170.

Ravolanirina, F., S. Gianinazzi, A. Trouvelot, and M. Carre. 1989a. Production of endomycorrhizal explants of micropropagated grapevine rootstocks. Agr. Ecosystems Environ. 29:323-327.

Ravolanirina, F., V. Gianinazzi-Pearson, and S. Gianinazzi. 1987. Preliminary studies on in vitro endomycorrhizal inoculation of micropropagated tree species of nutritional value, p. 91101. In: F.S.P. Ng (ed.). Trees and mycorrhiza. Proc. Asian Seminar, Intl. Found. Sci., Forest Res. Inst., Malaysia.

Schubert, A., M. Mazzitelli, O. Ariusso, and I. Eynard. 1990. Effects of vesicular-arbuscular mycorrhizal fungi on micropropagated grapevines: Influence of endophyte strain, P fertilization and growth medium. Vitis 29:5-13. 